\title{
Evaluation of Toxicity and Anti-Oxidation Activity of the Extracts from Halymenia durvillei
}

\author{
Athit Chaiwichien $^{1}$, Tepparit Samrit ${ }^{1}$, Supawadee Osotprasit ${ }^{1}$, \\ Pornanan Kueakhai ${ }^{1}$, Prasert Sobhon ${ }^{2}$, Krai Meemon ${ }^{2}$, Nakorn Niamnont ${ }^{3}$, \\ Preeyanuch Manohong ${ }^{3}$, Kanta Pranweerapaiboon', \\ Montakan Tamtin ${ }^{4}$ and Narin Changklungmoa ${ }^{1, *}$
}

\author{
${ }^{I}$ Faculty of Allied Health Sciences and Research Unit for Vaccine and Diagnosis of Parasitic Diseases, \\ Burapha University, Chonburi 20131, Thailand \\ ${ }^{2}$ Faculty of Science, Department of Anatomy, Mahidol University, Bangkok 10700, Thailand \\ ${ }^{3}$ Faculty of Science, Department of Chemistry, King Mongkut's University of Technology Thonburi, \\ Bangkok 10140, Thailand \\ ${ }^{4}$ Coastal Aquatic Feed Research Institute, Coastal Fisheries Research and Development Bureau, \\ Department of Fisheries, Phetchaburi 76000, Thailand
}

('Corresponding author’s e-mail: narinchang@go.buu.ac.th)

Received: 27 October 2020, Revised: 14 May 2021, Accepted: 27 May 2021

\begin{abstract}
Halymenia durvillei (HD), a marine red alga, is believed to have potentials for pharmacological, nutritional and cosmetic applications. However, such potentials are acceptable only when their extracts are devoid of any adverse effects on human health. No previous research has been conducted the toxicity and anti-oxidation capacity of HD. Thus, the aim of this work was to investigate toxicity and antioxidation activities of HD extracts. In this study, the toxicity and anti-oxidation capacity of 5 fractions of HD solvent extracts, i.e., ethanol (HDET), hexane (HDHE), ethyl acetate (HDEA), butanol (HDBU), and aqueous (HDAQ) were evaluated. The cytotoxicity was evaluated by MTT and LDH assays on 4 cell types, i.e., fibroblast, macrophage, hepatocyte and keratinocyte. The genotoxicity was evaluated by comet assay and micronucleus test using TK6 lymphoblastoid cell line. The anti-oxidation capacity was investigated by DPPH and ABTS assays. The toxicity studies showed that HDET, HDBU, HDAQ had very low to no toxicity as indicated by cytotoxicity and genotoxicity tests while HDEA, HDHE have some toxicity at high concentrations. HDAQ showed low antioxidant activity while HDET, HDEA, HDHE and HDBU possess relatively high antioxidant activity. Overall, our results indicated that HDET and HDAQ could be consumed as they are not toxic and HDHE, HDEA, and HDBU could be safely consumed at doses lower than $100 \mu \mathrm{g} / \mathrm{mL}$. Further investigation using in vivo assays are needed to ensure the safety of HD extracts for animal and human consumptions.
\end{abstract}

Keywords: Halymenia durvillei, Cytotoxicity, Genotoxicity, Antioxidant, Safety

\section{Introduction}

Macroalgae, including marine algae from the Protista orders, Phaeophyta (brown), Chlorophyta (green), and Rhodophyta (red), have a long history of being used as human diet [1]. Marine algae are a low-calorie food, which contain a high concentration of minerals, vitamins, and proteins and low lipid content [2]. Furthermore, marine algae produce many bioactive secondary metabolites such as polyphenolic compounds, polysaccharides, steroids, fatty acids, carotenoids, mycosporine-like amino acids, halogenated compounds, polyketides, lectins, peptides and their derivatives $[3,4]$ which have been used in biomedical applications. In addition to the above-mentioned compounds, red seaweed of Halymenia spp. also contains several other useful compounds, for examples, $H$. durvillei has a high amount of sulfated galactan [5], Halymenia floresii (H. floresii) has monohydroxy acetylated sterolhalymeniaol which has been reported to exert antimalarial effect [6], Sulfated galactan from Halymenia dilatate $(H$. dilatate) showed enhanced the antioxidant properties and prevents Aeromonas hydrophila infection [7], and 3-(Hydroxyacetyl)indole and Indole-3-carboxylic acid from ethyl acetate extract of $H$. durvillei showed anti-lung cancer cell and in vivo anti-aging activity [8]. Because of the richness of these 
natural compounds, $H$. durvillei (HD), the red seaweed that is widely grown in Thailand water, is considered as an excellent starting material which can be processed into pharmaceutical, nutraceutical and cosmeceutical products for humans. However, the extracts from this sea weed must first be tested for their toxicity and oxidative capacity before being developed into safe consumable products. In this study, we tested solvent extracts of HD for their cytotoxicity in causing cell lysis and death by LDH and MTT assays, and possible genotoxicity, especially the breakage of DNA and chromosomes, by Comet and Micronucleus essays. In addition, we also tested the antioxidation capacity of the HD extracts for their possible uses as antioxidants to mop up free radicals that may be damaging to cells. Free radicals are atoms or molecules which contain one or more unpaired electrons. Free radicals consist mainly of reactive oxygen species (ROS), such as the superoxide radical $\left(\mathrm{O}_{2}{ }^{-}\right)$and hydrogen peroxide $\left(\mathrm{H}_{2} \mathrm{O}_{2}\right)$, which possess powerful oxidizing capacities that enable them to react with macro- and micro-molecules such as proteins, nucleic acids, or lipids. This event can cause protein misfold, DNA damage, and lipid peroxidation that are highly damaging to cells and cause pathogenesis of several human diseases [9-11]. In the present study we tested the antioxidant capacity of the HD extracts by DPPH and ABTS assays.

\section{Materials and methods}

\section{Plant materials and crude extraction}

H. durvillei was pond-cultured by Ms. Montakan Tamtin, Phetchaburi Coastal Fisheries Research and Development Center, Thailand. The algae were extensively washed with tap water and dried at room temperature (RT). One kilogram of air-dried $H$. durvillei, was milled and macerated successively with $5 \mathrm{~L}$ $95 \% \mathrm{EtOH}$ at RT for 7 days. Next, the EtOH extract was successively partitioned in solvents with increasing polarity from n-hexane (HE), ethyl acetate (EA), n-butanol (BU) and distilled water (AQ) according to Manohong et al. [8]. The yields after evaporation of the solvents under reduced pressure were compared with dried weight of the seaweed, which for various fractions designated as HDET, HDHE, HDEA, HDBU, HDAQ were 4.47, 5.33, 1.49, 6.34 and $10.89 \%$, respectively. The extracts were then filtered and evaporated under vacuum. Powders from the extracts were dissolved in $100 \%$ DMSO at $1 \mathrm{mg} / \mathrm{mL}$ and kept as stock solutions and stored at $-20^{\circ} \mathrm{C}$.

\section{Cells and cell culture}

Mouse fibroblast (L929), mouse macrophages (RAW 264.7), mouse hepatocyte (FL83B), keratinocytes (HaCaT), and human lymphoblast cells (TK6) were purchased from American Type Culture Collection (ATCC). RAW264.7 and TK6 cells were cultured in RPMI medium supplemented with $10 \%$ fetal bovine serum (FBS) and $100 \mathrm{U} / \mathrm{mL}$ penicillin/100 $\mu \mathrm{g} / \mathrm{mL}$ streptomycin. L929, FL83B, and HaCaT cells were cultured in DMEM medium supplemented with $10 \% \mathrm{FBS}$ and $100 \mathrm{U} / \mathrm{mL}$ penicillin $/ 100 \mu \mathrm{g} / \mathrm{mL}$ streptomycin. The cells were maintained at $37{ }^{\circ} \mathrm{C}$ in a humidified atmosphere with $5 \% \mathrm{CO}_{2}$ and passaged every 2 - 3 days when they were approximately $90 \%$ confluent. For treatments with HD extracts, cells were collected under exponential growth phase and seeded at adjusted density for different culture flasks or well plates. When they reached the confluence, cells were washed twice with phosphate buffered saline (PBS) and then treated with fresh medium containing HD extracts.

\section{MTT cytotoxicity assay}

For the MTT assay [12,13], $8 \times 10^{3}$ cells/wells of each cell type were seeded into 96-well plate and incubated for $24 \mathrm{~h}$ until cells attached to the plate before adding the extracts. After the incubation period, the cells were treated with HD extracts at concentrations ranging from $10-1,000 \mu \mathrm{g} / \mathrm{mL}$ for $24 \mathrm{~h}$. Then culture medium was discarded and $1 \mathrm{~mL}$ of MTT reagent $(5 \mathrm{mg} / \mathrm{mL}$ ) (Sigma-Aldrich, U.S.A.) in PBS was added to each well. The plates were incubated at $37{ }^{\circ} \mathrm{C}$ for $3 \mathrm{~h}$. At the end of the incubation period, the medium was removed and $100 \mu \mathrm{L}$ DMSO (analytical grade) was added to each well to dissolve insoluble formazan crystals. The color being formed by formazan crystals was measured by reading the absorbance at $570 \mathrm{~nm}$ in a microplate reader (VersaMax microplate reader). The percentage of viable cells was calculated after normalization with the negative control (PBS), which was considered to have $100 \%$ cell viability. The cytotoxicity value was presented as IC50 (the median growth inhibitory concentration) of the extracts. IC50 values were calculated by GraphPad Prism 7 software.

\section{LDH cytotoxicity assay}

For LDH assay [12,13], $100 \mu \mathrm{l}$ of $8 \times 10^{3}$ cells/wells of each cell type in culture medium were seeded into 96-well plate and incubated for $24 \mathrm{~h}$ when cell attachment was completed. Then, the cells were treated with seaweed extracts by adding $100 \mu \mathrm{L} /$ well of various concentrations of the extracts ranging 
from 10 to $1000 \mu \mathrm{g} / \mathrm{mL}$, and incubated at $37^{\circ} \mathrm{C}$ in a humidified atmosphere of $95 \%$ air and $5 \%$ of $\mathrm{CO}_{2}$ for $24 \mathrm{~h}$. At the end of incubation period, $5 \mu \mathrm{L}$ of lysis solution (Roche, U.S.A.) was added to the well as a positive (high) control while the well without the extracts and lysis solution was used as a negative (low) control. The plate was incubated for an additional $15 \mathrm{~min}$. A $50 \mu \mathrm{L}$ of culture medium was transferred from each well to a new 96 well plate. Then, $100 \mu \mathrm{L}$ of the freshly prepared reaction mixture for LDH activity from LDH kit (Roche, U.S.A.) was added to each well on the 96-well plate and incubated for $30 \mathrm{~min}$ at room temperature (RT) in the dark. Finally, $50 \mu \mathrm{L}$ of stop solution (Roche, U.S.A.) was added to each well on the 96-well plate. The reduction of yellow tetrazolium salt, INT, by NADH into a red, water-soluble formazan-class dye was determined by a microplate reader (VersaMax microplate reader) at a wavelength of $490 \mathrm{~nm}$ and percent cytotoxicity of each extract was calculated based on the following equation;

LDH activity $(\%)=\frac{\text { exp. value }- \text { low control }}{\text { high control }- \text { low control }} \times 100$

\section{Comet assay for genotoxicity test}

For comet assay [12,13], $100 \mu \mathrm{L}$ of $2 \times 10^{5}$ cells/well of lymphoblast cells in RPMI medium were seeded into 24-well plate and incubated for $24 \mathrm{~h}$. After the incubation period, the cells were treated with seaweed extracts at concentrations ranging from 10 to $1,000 \mu \mathrm{g} / \mathrm{mL}$ for $24 \mathrm{~h}$. After the incubation, an aliquot of $1 \times 10^{5}$ cells were centrifuged for $5 \mathrm{~min}$ at $3,000 \mathrm{rpm}$, then the incubation medium was removed and the pellet was washed with PBS pH 7.4. The cells in PBS were resuspended in molten low melting point (LMP) agarose at a ratio of 1:10 (v/v). $100 \mu \mathrm{L}$ of cells in LMP agarose was laid on a glass slide precoated with $1 \%$ normal melting point agarose. After gel solidified at RT, the slides were placed in a Coplin jar and immersed in ice-cold lysis solution (2.5 M NaCl, 0.1 M EDTA, $10 \mathrm{mM}$ Tris base, pH10, supplemented with $1 \%$ Triton X-100) for overnight at $4{ }^{\circ} \mathrm{C}$ in the dark, to lyse the cells and separated DNA from histones. The lysis solution was removed and slides were immersed in DNA unwinding solution $(0.3 \mathrm{M} \mathrm{NaOH}, 1 \mathrm{mM}$ EDTA, $\mathrm{pH} 13)$ for $20 \mathrm{~min}$ in the dark at room temperature, followed by gel electrophoresis at $20 \mathrm{~V}$ for $20 \mathrm{~min}$. Finally, slides were neutralized with neutralization buffer $(0.4 \mathrm{M}$ Tris, $\mathrm{pH} 7.5$ ) for $5 \mathrm{~min}$, then stained with an SYBR Green. Images were immediately taken with fluorescence microscope at $400 \times$ magnification, and analyzed by the image analysis software CometScore 2.0. The results were recorded by examining at least 50 randomly selected nonoverlapping cells per culture well with a double-blind observation. Following parameters were recorded: tail length, \%tail DNA, and tail moment. Tail length was the length of the comet tail indicating the extent of DNA breakage. \%Tail DNA was the fluorescence intensity from the UV-illuminated damaged DNA in the comet tail, and the tail moment was calculated from tail length multiply by \%tail DNA. The data from the experimental groups were compared with the blank control.

\section{Micronucleus test (MN)}

For the micronucleus test [12,13], $2 \times 10^{5}$ cells/wells of lymphoblasts in the RPMI medium were seeded into 24-well plate and incubated for $24 \mathrm{~h}$. At the end of incubation, cells were centrifuged at 3,000 $\mathrm{rpm}$ for $5 \mathrm{~min}$. The cells were collected and resuspended in fresh culture medium and transferred to a new 24-well plate. A $6 \mu \mathrm{g} / \mathrm{mL}$ of cytochalasin B was added to each well and incubated for $24 \mathrm{~h}$, after which cells at binucleated stage were collected by centrifugation at $3000 \mathrm{rpm}$ for $5 \mathrm{~min}$, and subjected to a hypotonic solution $(5 \mathrm{~mL}$ of $0.075 \mathrm{M} \mathrm{KCl})$ followed by another centrifugation. The cells were collected and fixed with methanol/glacial acetic acid (3:1), centrifuged, and the pellet was resuspended in a small volume of fresh fixative, and then $20 \mu \mathrm{L}$ drops were laid on a clean microscope slide. After drying, the cells were stained with $2 \%$ Giemsa-Romanowski solution for $10 \mathrm{~min}$. Micronuclei (MN) formation was scored among 1,000 binucleated cells $(\mathrm{BNC})$ under a light microscope $(40 \times)$ and the frequency $(\%)$ of micronucleated cells were determined.

\section{DPPH anti-oxidation assay}

DPPH assay [14,15] comprised 4 groups: group I (Sample+Met), each of the 5 fractions of $H$. durvillei was diluted with methanol at concentrations $250,500,750,1,000,1500$ and 2,000 $\mu \mathrm{g} / \mathrm{mL}$. A 0.1 $\mathrm{mL}$ of each concentration was mixed with $0.1 \mathrm{~mL}$ of methanol in 96-well plate; group II (Met), $0.2 \mathrm{~mL}$ of methanol was added in each well of the 96-well plate; group III (DPPH+Met), a $0.1 \mathrm{~mL}$ of DPPH working solution was mixed with $0.1 \mathrm{~mL}$ of methanol in 96-well plate; and group IV (Sample+DPPH), each fraction of $H$. durvillei extracts and positive controls $(2,4,6,8$, and $10 \mu \mathrm{g} / \mathrm{mL}$ of vitamin $\mathrm{C}$ and quercetin) were diluted with $0.1 \mathrm{~mL}$ methanol, then they were mixed with $0.1 \mathrm{~mL}$ of DPPH working 
solution. After that, all samples in each group were thoroughly mixed and left standing at room temperature in the dark for $30 \mathrm{~min}$. Finally, the absorbance of each sample was measured at $517 \mathrm{~nm}$. The EC50 value of each fraction was extrapolated from the linear equation by substituting the percent of scavenging effect (y) at $50 \%$.

\section{ABTS anti-oxidation assay}

ABTS assay [16] also comprised 4-groups: group I (Sample+Met), a $0.1 \mathrm{~mL}$ of each concentration of the $5 \mathrm{H}$. durvillei extracts (diluted with methanol at 250, 500, 750, 1,000, 1,500 and 2,000 $\mu \mathrm{g} / \mathrm{mL}$ ) was mixed with $0.1 \mathrm{~mL}$ of methanol in 96-well plates; group II(Met), $0.2 \mathrm{~mL}$ of methanol was added to each well of the 96-well plates; group III(ABTS+Met), $0.1 \mathrm{~mL}$ of methanol and $0.1 \mathrm{~mL}$ of ABTS reagent were mixed in each well on the 96-well plates; and group IV (Sample+ABTS) a $0.1 \mathrm{~mL}$ of each concentration of the 5 fractions of $\mathrm{H}$. durvillei and positive controls $(2,4,6,8$, and $10 \mu \mathrm{g} / \mathrm{mL}$ of vitamin $\mathrm{C}$ and quercetin) were diluted with $0.1 \mathrm{~mL}$ methanol, then they were mixed with $0.1 \mathrm{~mL}$ of DPPH working solution. All samples were thoroughly mixed and incubated at room temperature in the dark for 20 min. After that, the absorbance of each sample was measured at $734 \mathrm{~nm}$. The EC50 value of each fraction was extrapolated from the linear equation by substituting the percent of scavenging effect (y) at $50 \%$.

\section{Statistical analysis}

Results are presented as mean \pm standard deviation (S.D.). One-way analysis of variance (ANOVA) followed by Dunnett's test were used to determine significant differences between extracts and controls or vehicles. These analyses were performed using GraphPad Prism 7 for Windows. The significance level was inferred at $p<0.001$ for all statistical tests.

\section{Results and discussion}

\section{Cytotoxicity of extracts from $H$. durvillei by MTT and LDH assays}

In MTT assay, after $24 \mathrm{~h}$ the IC50 of HDET and HDAQ for all cell types were more than 1,000 $\mu \mathrm{g} / \mathrm{mL}$ which indicated that these fractions were non-cytotoxic. IC50 of HDHE, HDEA and HDBU for L929 cells, were $316.7,514.7$, and $531.0 \mu \mathrm{g} / \mathrm{mL}$, for FL83B cells IC50 were 143.5, 171.3, and 425.6 $\mu \mathrm{g} / \mathrm{mL}$, for RAW 264.7 cells IC50 were 127.6, 229.6, and $456.4 \mu \mathrm{g} / \mathrm{mL}$, and for HaCaT cells, IC50 were $302.8,702.1$, and $936.7 \mu \mathrm{g} / \mathrm{mL}$, respectively. These results indicated that HDHE, HDEA and HDBU had some cytotoxic effect ranging from relatively high to low (Figure 1). Table of IC50 values of MTT assay were shown in Table 1. In LDH assay, IC50 of HDET and HDAQ after $24 \mathrm{~h}$ incubation for all cell types were more than $1,000 \mu \mathrm{g} / \mathrm{mL}$, indicating that these fractions were not toxic. IC50 of HDHE, HDEA and HDBU for L929 cells were $212.4,>1,000,>1,000 \mu \mathrm{g} / \mathrm{mL}$, for FL83B cells IC50 were 489.4, >1,000, $>1,000 \mu \mathrm{g} / \mathrm{mL}$, for RAW 264.7 cells IC50 were $177.6,>1,000,475.2 \mu \mathrm{g} / \mathrm{mL}$, and for HaCaT cells, IC50 were $483.0,>1,000,>1,000 \mu \mathrm{g} / \mathrm{mL}$. These results indicated that HDHE had some toxicity while HDEA and HDBU were relatively less toxic (Figure 2). Table of IC50 values of LDH assay was shown in Table 2.

Table 1 IC50 values of MTT assay.

$\operatorname{IC50}(\mu \mathrm{g} / \mathrm{mL})$

Fractions

Cell lines

\begin{tabular}{ccccc}
\cline { 2 - 4 } & L929 & RAW 264.7 & FL83B & HaCaT \\
\hline HD-ET & $>1,000.00$ & $>1,000.00$ & $>1,000.00$ & $>1,000.00$ \\
\hline HD-HE & 316.70 & 127.60 & 143.50 & 302.80 \\
\hline HD-EA & 514.70 & 229.60 & 171.30 & 702.10 \\
\hline HD-BU & 531.00 & 456.40 & 425.60 & 936.70 \\
\hline HD-AQ & $>1,000.00$ & $>1,000.00$ & $>1,000.00$ & $>1,000.00$ \\
\hline
\end{tabular}


(A)

L929 cell

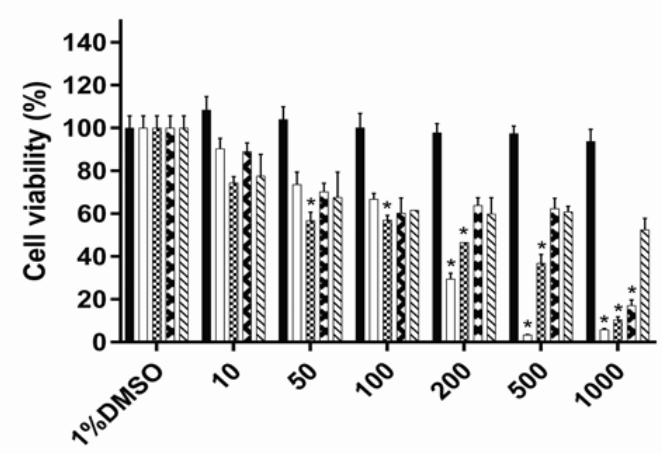

Concentrations $(\mu \mathrm{g} / \mathrm{ml})$

(C)

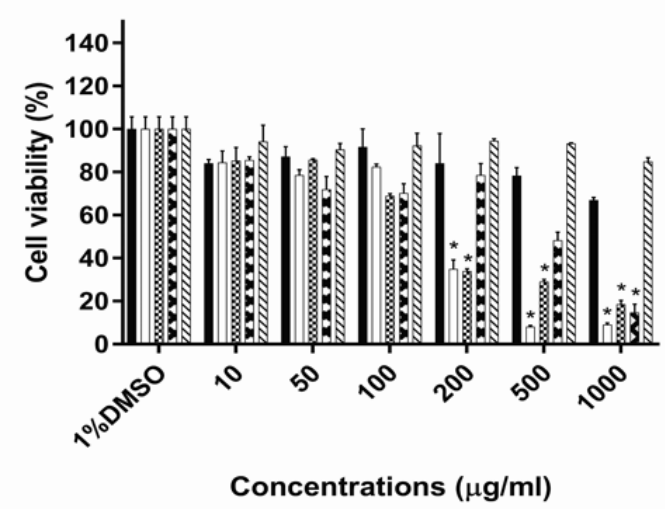

(B)

RAW264.7 cell

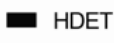

$\square$ HDHE

HDEA

$\boldsymbol{x}$ HDBU

HIV HDA

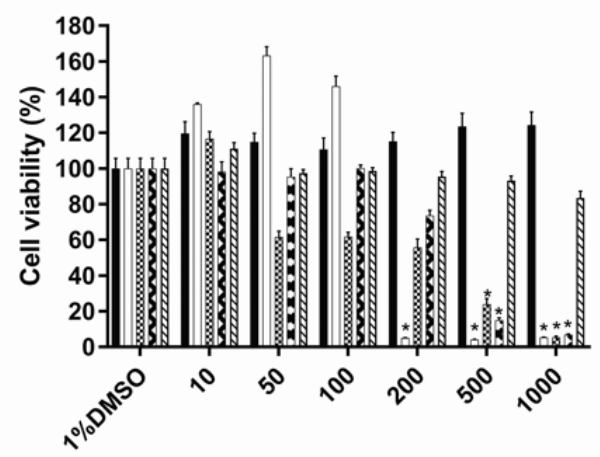

Concentrations $(\mu \mathrm{g} / \mathrm{ml})$

(D)

HaCaT cell

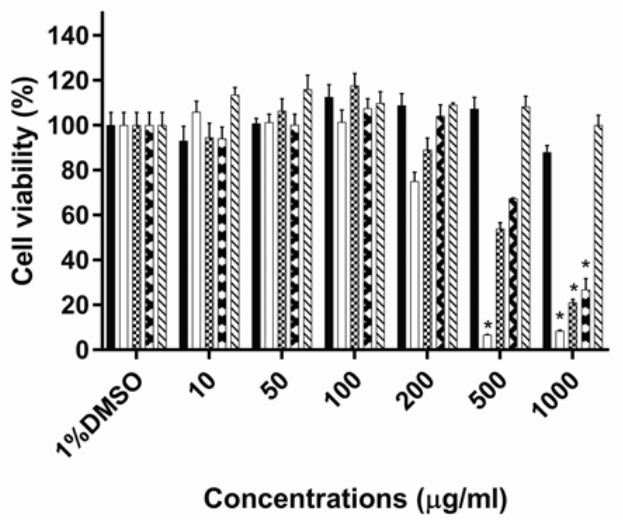

Figure 1 Cell viability of 4 cell types treated with $H$. durvillei extracts for $24 \mathrm{~h}$ as determined by the MTT assay. (A) L929 cells; (B) RAW264.7 cells; (C) FL83B cells; (D) HaCaT cells. Data were expressed as mean \pm standard deviation of the percentage of cell viability in relation to $1 \%$ DMSO which is used a negative control with $100 \%$ cell viability, ${ }^{*} p<0.001$.

Table 2 IC50 values of LDH assay.

\section{$\operatorname{IC50}(\mu \mathrm{g} / \mathrm{ml})$}

Fractions

\section{Cell lines}

\begin{tabular}{ccccc} 
& L929 & RAW 264.7 & FL83B & HaCaT \\
\hline HD-ET & $>1,000.00$ & $>1,000.00$ & $>1,000.00$ & $>1,000.00$ \\
\hline HD-HE & 212.40 & 177.60 & 489.40 & 483.00 \\
\hline HD-EA & $1,596.00$ & $>1,000.00$ & $>1,000.00$ & $>1,000.00$ \\
\hline HD-BU & $1,443.00$ & 475.20 & $>1,000.00$ & $>1,000.00$ \\
\hline HD-AQ & $>1,000.00$ & $>1,000.00$ & $>1,000.00$ & $>1,000.00$
\end{tabular}


(A)

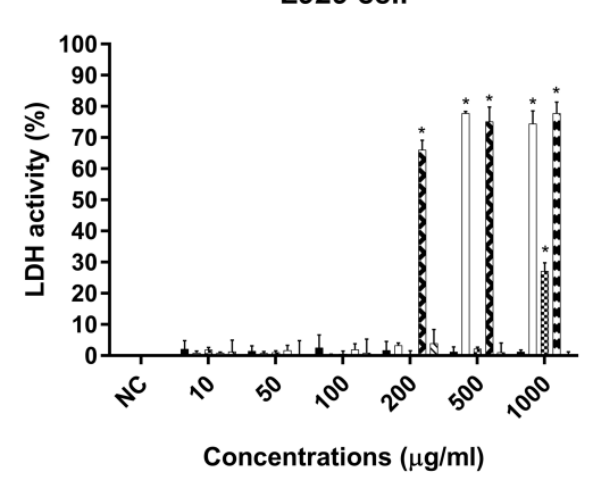

(C)

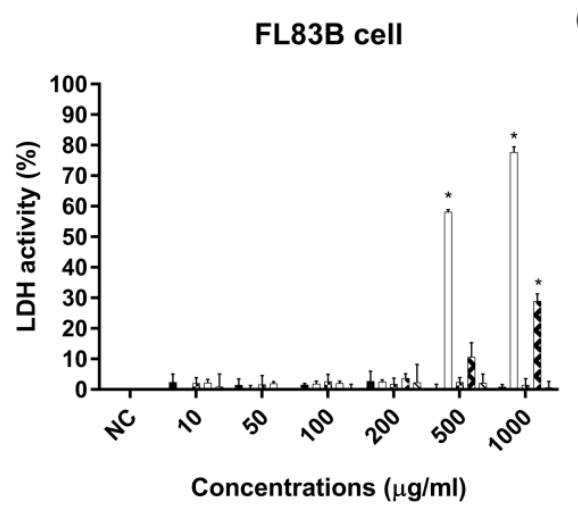

(B)

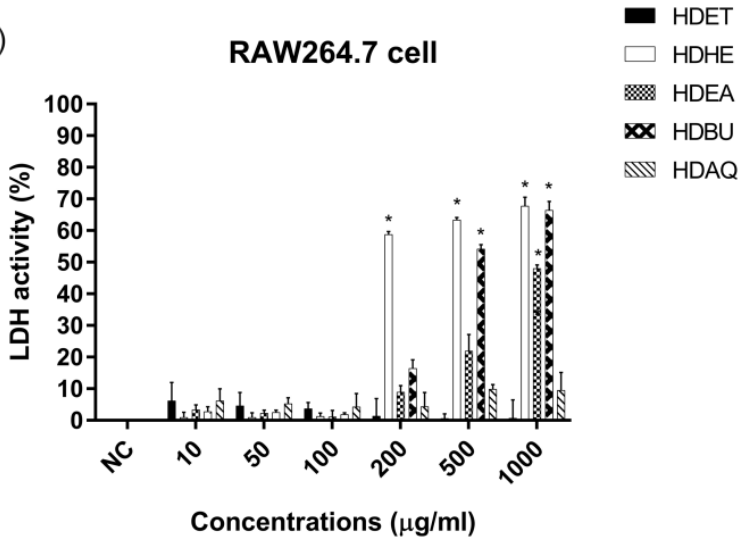

(D)

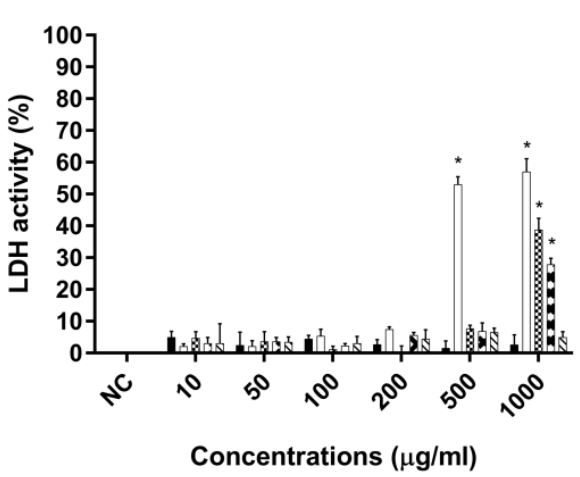

Figure $2 \mathrm{LDH}$ activity of 4 cell types treated with $H$. durvillei extracts for $24 \mathrm{~h}$, as determined by LDH assay: (A) L929 cells; (B) RAW264.7 cells; (C) FL83B cells; (D) HaCaT cells. Data were expressed as mean \pm standard deviation of the percentage of $\mathrm{LDH}$ activity in relation to the positive control $(100 \%$ LDH activity), ${ }^{*} p<0.001$.

Therefore, from these data it can be concluded that HDET and HDAQ fractions were not toxic with IC50 values more than $1,000 \mu \mathrm{g} / \mathrm{mL}$, whereas HDHE, HDEA and HDBU showed some degree of cytotoxicity against the 4 cell lines. Our results from the 2 cytotoxic assays showed that the lowest to the highest toxicity of the extracts were HDAQ, HDET, HDBU, HDEA, and HDHE, respectively. Prolonged exposure and higher concentrations of treatments with HDEA and HDHE showed higher toxic effect and lower IC50 value as reported earlier [17]. We found from our initial screening that phytochemicals in extracts from $H$. durvillei contained alkaloids, carotenoids, flavonoids, terpenoids, steroids, glycoside, saponins, and phenolic compounds (unpublished data). These secondary metabolites are exogenous antioxidants that contain in the extract may give either valuable or adverse outcomes in redox balance depending on concentrations being tested or doses being consumed [18,19]. Besides, a few studies showed that exogenous antioxidants gave debatable results, especially at high doses. The type, concentration, and matrix of exogenous antioxidants from a natural compound are the features that affect the balance of the benefits [18]. In general, the cytotoxic activity of a plant against cancer cells is based on their phytochemical properties [19]. These reports are consistent with our study which tend to be at higher concentrations in HDHE, HDEA, and HDBU, can have both useful and harmful effects on cells. Most of these compounds have antioxidant activity which is beneficial to cell survival while some compound like saponin, a membranolytic agent, can exert harmful effect on cells. HDHE, HDEA, and HDBU tended to have higher concentration of saponins than HDET and HDAQ. Saponin has an ability to form complexes with membrane cholesterol leading to pore formation and membrane permeabilization, and it also causes alterations in the negatively charged carbohydrate portions on the cell surface [20-22]. Cytotoxic effects of saponins have been demonstrated in some normal cell lines like fibroblast [23-27], macrophage [28-29], and keratinocyte [30]. These could explain the relatively higher degree of 
cytotoxicity of HDHE and HDEA. The above-mentioned substances, including saponin, should also be present in HDET, but the concentrations were too low to cause cytotoxic effect.

Table 3 Genotoxicity was measured by comet assay for tail length, \%tail DNA and tail moment in TK6.

\begin{tabular}{cccc}
\hline Treatment & Tail Length \pm SD & \% Tail DNA \pm SD & Tail moment \pm SD \\
\hline Negative control & 0 & 0 & 0 \\
Positive control $\left(\mathrm{H}_{2} \mathrm{O}_{2}\right)$ & $38.97 \pm 6.78$ & $44.05 \pm 9.04$ & $38.97 \pm 6.78$ \\
HDET $1,000 \mu \mathrm{g} / \mathrm{mL}$ & $1.59 \pm 1.55$ & $4.81 \pm 2.20$ & $0.14 \pm 0.22$ \\
HDHE $100 \mu \mathrm{g} / \mathrm{mL}$ & $51.93 \pm 38.15^{*}$ & $35.13 \pm 28.44^{*}$ & $27.56 \pm 33.27^{*}$ \\
HDHE $200 \mu \mathrm{g} / \mathrm{mL}$ & $60.46 \pm 21.52^{*}$ & $72.91 \pm 10.55^{*}$ & $54.62 \pm 29.45^{*}$ \\
HDHE $500 \mu \mathrm{g} / \mathrm{mL}$ & $72.26 \pm 25.26^{*}$ & $79.68 \pm 14.55^{*}$ & $75.24 \pm 21.06^{*}$ \\
HDHE $1,000 \mu \mathrm{g} / \mathrm{mL}$ & N/A & N/A & N/A \\
HDEA $500 \mu \mathrm{g} / \mathrm{mL}$ & $88.93 \pm 25.71^{*}$ & $71.70 \pm 11.99^{*}$ & $65.83 \pm 27.92^{*}$ \\
HDEA $1,000 \mu \mathrm{g} / \mathrm{mL}$ & N/A & N/A & N/A \\
HDBU $500 \mu \mathrm{g} / \mathrm{mL}$ & $89.70 \pm 11.76^{*}$ & $70.25 \pm 9.46^{*}$ & $63.66 \pm 14.72^{*}$ \\
HDBU $1,000 \mu \mathrm{g} / \mathrm{mL}$ & N/A & N/A & N/A \\
HDAQ $1,000 \mu \mathrm{g} / \mathrm{mL}$ & $1.68 \pm 2.21$ & $6.31 \pm 3.10$ & $0.07 \pm 0.08$ \\
\hline
\end{tabular}

$\mathrm{S} . \mathrm{D}=$ Standard Deviation; $\mathrm{H}_{2} \mathrm{O}_{2}=$ Hydrogen Peroxide

Significant difference from the control group are calculated and marked with asterisks $\left({ }^{*} p<0.001\right.$ vs negative control).

\section{Genotoxicity of extracts from $\boldsymbol{H}$. durvillei by Comet assay and Micronucleus test}

The results of the genotoxic effects of the extracts from HD on TK6 cell line were presented as the changes in tail length (TL), percentage of DNA in tail (\%DNA), and tail moment (TM). HDHE, HDEA and HDBU exhibited genotoxic effects on TK6 cells by significant increases of TL, \% DNA, and TM at concentrations above $100 \mu \mathrm{g} / \mathrm{mL}$ for HDHE, $500 \mu \mathrm{g} / \mathrm{mL}$ for HDEA and HDBU. On the other hand, TK6 cells treated with HDET and HDAQ showed no significant changes in TL, \%DNA and TM even at maximum concentration of $1,000 \mu \mathrm{g} / \mathrm{mL}$. These results indicated that HDET and HDAQ had no genotoxic effect, while HDHE was safe at concentrations less than $100 \mu \mathrm{g} / \mathrm{mL}$, and HDEA and HDBU at concentration less than $500 \mu \mathrm{g} / \mathrm{mL}$ (Figure 3, Table 3). In micronucleus test chromosomal damage in TK6 cells was shown by the formation of micronuclei containing either chromosome fragments or whole chromosomes beside the dividing binucleated nuclei (Figure 4A). The result showed that untreated cells (negative control) exhibited a baseline frequency of micronuclei at $0 \%$ and all cells appeared binucleated (Figure 4C). In contrast, micronucleus formation was induced by mitomycin c treatment (positive control) at $57.89 \%$ where the abnormal cells appeared binucleated with micronuclei (Figure 4D). TK6 cells treated with HDET and HDAQ showed no micronuclei, indicating that these fractions were not genotoxic. On the other hand, TK6 cells treated with HDHE, HDEA, and HDBU exhibited some degree of genotoxicity at concentration between 200 and $500 \mu \mathrm{g} / \mathrm{mL}$. The percentages of cells bearing micronuclei after treatments with HDHE were 12.44 and $36.94 \%$, with HDEA were 19.6 and $28.24 \%$, and with HDBU were 16.18 and $22.41 \%$ (Table 4). These results indicated that HDET and HDAQ had no genotoxic effect, while HDHE, HDEA and HDBU were safe at concentrations less than $100 \mu \mathrm{g} / \mathrm{mL}$ at which no micronuclei occurred.

Information on the genotoxicity of $H$. durvillei is scant. Human lymphoblastoid or TK6 cells have been widely used to test genotoxic effect of compounds, with high sensitivity [31]. Comet parameters used in measuring DNA damage in cells included the percentage of DNA in the tail (\% tail DNA), tail length (TL), and tail moment (TM) calculated from fluorescence intensity observed under fluorescent microscope. Our result from comet assay showed that HDET, and HDAQ at the highest concentration at $1,000 \mu \mathrm{g} / \mathrm{mL}$ showed no genotoxicity, whereas HDHE, HDEA, and HDBU showed some degree of genotoxicity at concentrations higher than 100,500 and $500 \mu \mathrm{g} / \mathrm{mL}$, respectively. In micronucleus assay HDHE, HDEA, and HDBU caused significant increase of micronucleus frequency $(\% \mathrm{MN})$ in TK6 cells 
at concentrations higher than 500, 1,000 and 1,000 $\mu \mathrm{g} / \mathrm{mL}$, respectively. By contrast, HDET, and HDAQ did not cause chromosome damage even at the highest dose $(1,000 \mu \mathrm{g} / \mathrm{mL})$ being tested. Tonelli et al. [32] indicated that the comet and MN assays could detect genotoxic effects by different mechanisms. The comet assay is generally more sensitive than the MN assay [33,34], as it detects DNA raveling and strand breaks [35], while micronucleus originates later during anaphase from acentric chromosomes or chromatid fragments caused by the disrepair of DNA breaks [36]. Thus, this explained the genotoxicity of HDHE, HDEA, and HDBU at lower doses in comet assay.

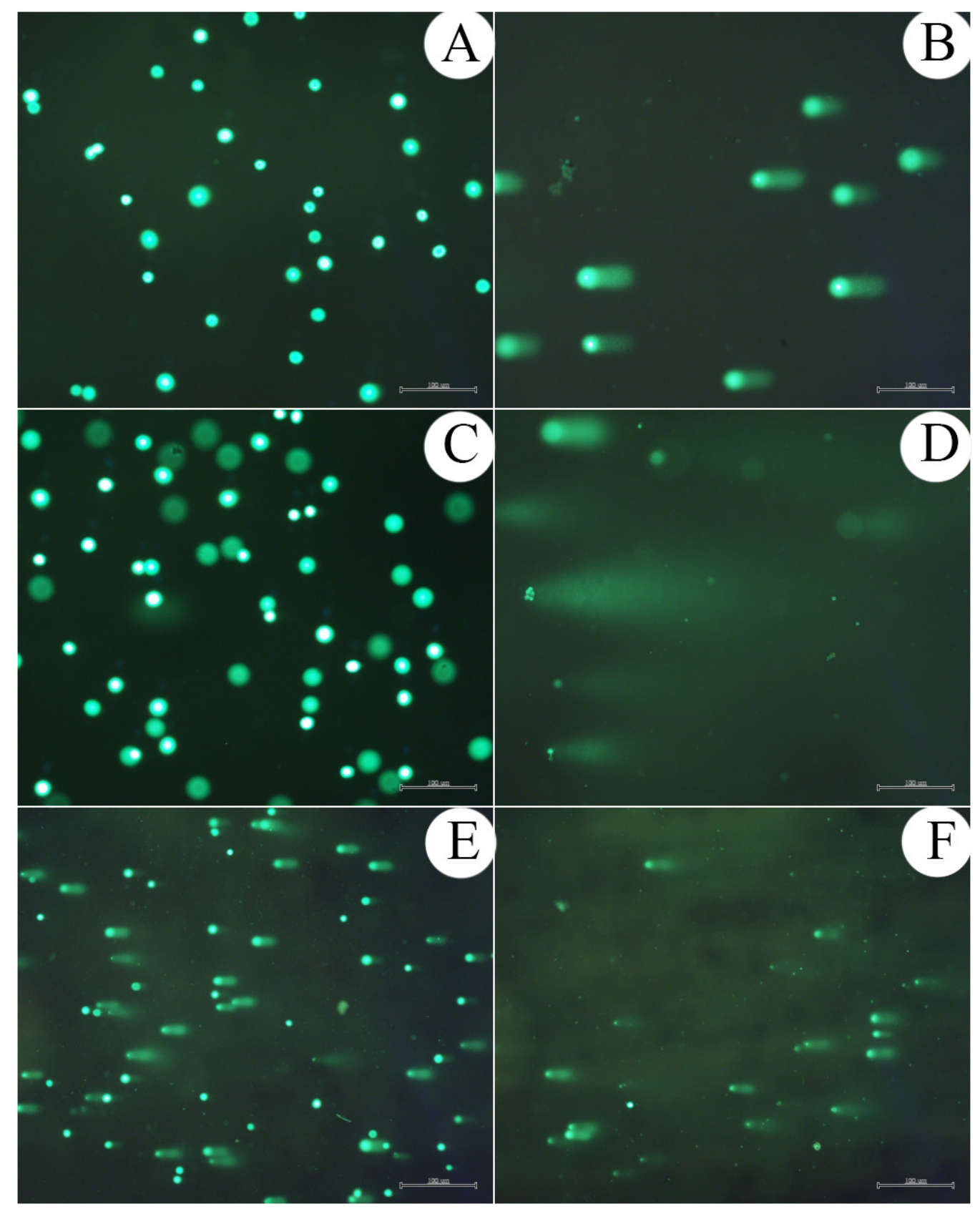

Figure 3 Genotoxicity by comet assay was performed on TK6 cell. The expression of DNA damage as appeared in the comet tail was analyzed by Comet Score 2.0 software. Representative images (at $400 \times$ magnification) of TK6 cells after $24 \mathrm{~h}$ of exposure to $\mathrm{HD}$ extracts and $\mathrm{H}_{2} \mathrm{O}_{2}(50 \mu \mathrm{M})$ as a positive control are as follows: A) Negative control, B) Positive control, C) HDET $1000 \mu \mathrm{g} / \mathrm{mL}$, D) HDHE $500 \mu \mathrm{g} / \mathrm{mL}$, E) HDEA $500 \mu \mathrm{g} / \mathrm{mL}$, F) HDBU $500 \mu \mathrm{g} / \mathrm{mL}$. Long tail of comet-liked appearance is indicative of DNA damage. Scale bar: $100 \mu \mathrm{m}$ for all images. 
Table 4 Genotoxicity as measured by micronucleus assay showing $\%$ of TK 6 cells with micronuclei after treatment with $H$. durvillei extracts for $24 \mathrm{~h} .{ }^{*} p<0.001$ vs negative control).

\begin{tabular}{ccc}
\hline Treatment & $\begin{array}{c}\text { The mean values of micronucleus } \\
\text { frequencies/ 1000 BNC } \pm \text { SD }\end{array}$ & Micronucleus (\%) \\
\hline Mitomycin C $1 \mu \mathrm{g} / \mathrm{mL}$ & $578.90 \pm 26.45$ & 57.89 \\
(Positive control) & 0 & 0 \\
HDET $1,000 \mu \mathrm{g} / \mathrm{mL}$ & $43.05 \pm 6.55$ & 4.30 \\
HDHE $100 \mu \mathrm{g} / \mathrm{mL}$ & $124.41 \pm 19.97$ & 12.44 \\
HDHE $200 \mu \mathrm{g} / \mathrm{mL}$ & $369.42 \pm 15.93^{*}$ & $36.94^{*}$ \\
HDHE $500 \mu \mathrm{g} / \mathrm{mL}$ & $\mathrm{N} / \mathrm{A}$ & $\mathrm{N} / \mathrm{A}$ \\
HDHE $1,000 \mu \mathrm{g} / \mathrm{mL}$ & $25.57 \pm 6.84$ & 2.55 \\
HDEA $100 \mu \mathrm{g} / \mathrm{mL}$ & $32.48 \pm 9.27$ & 3.24 \\
HDEA $200 \mu \mathrm{g} / \mathrm{mL}$ & $196.03 \pm 24.58$ & 19.60 \\
HDEA $500 \mu \mathrm{g} / \mathrm{mL}$ & $282.24 \pm 27.21^{*}$ & $28.22 *$ \\
HDEA $1,000 \mu \mathrm{g} / \mathrm{ml}$ & $8.13 \pm 2.45$ & 0.81 \\
HDBU $100 \mu \mathrm{g} / \mathrm{mL}$ & $39.77 \pm 10.25$ & 3.97 \\
HDBU $200 \mu \mathrm{g} / \mathrm{mL}$ & $161.84 \pm 35.29$ & 16.18 \\
HDBU $500 \mu \mathrm{g} / \mathrm{mL}$ & $224.11 \pm 22.43^{*}$ & $22.41^{*}$ \\
HDBU $1,000 \mu \mathrm{g} / \mathrm{mL}$ & 0 & 0 \\
HDAQ $1,000 \mu \mathrm{g} / \mathrm{mL}$ & &
\end{tabular}

S.D $=$ Standard Deviation

Significant difference from the control group are calculated and marked with asterisks

$(* p<0.001$ vs negative control).

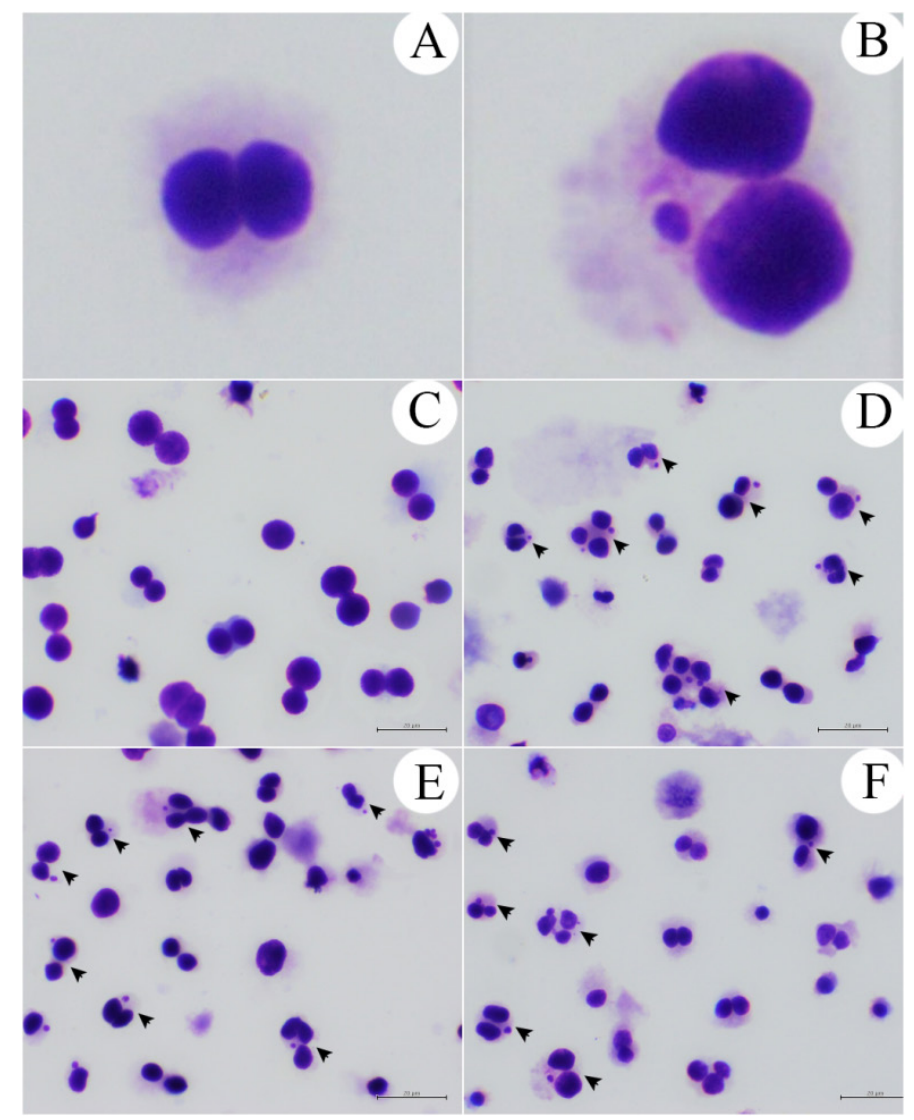

Figure 4 Genotoxicity was measured by micronucleus test. The expression of chromosome damage was displayed by binucleated cells (BNC) with micronucleus. Representative images (400× magnification) of TK6 cells after $24 \mathrm{~h}$ of exposure to $\mathrm{HD}$ extracts and mitomycin $\mathrm{C}(1 \mu \mathrm{g} / \mathrm{mL})$, used as positive control, are as follows: A) BNC (negative control), B) $\mathrm{BNC}$ with mitomycin $\mathrm{C}$ showing micronucleus (positive control), C) HDET 1,000 $\mu \mathrm{g} / \mathrm{mL}$, D) HDHE $500 \mu \mathrm{g} / \mathrm{mL}$, E) HDEA $500 \mu \mathrm{g} / \mathrm{mL}$, F) HDBU $500 \mu \mathrm{g} / \mathrm{mL}$. Scale bar: $100 \mu \mathrm{m}$ for all images. Arrow heads indicate binucleated cells with micronucleus. 
Anti-oxidation activity of $\boldsymbol{H}$. durvillei extracts by DPPH assay and ABTS assay

The anti-oxidation activity was reflected by the scavenging of DPPH • radicals which appeared in a concentration-dependent manner. The anti-oxidation (scavenging) activity of HDHE ranged from 11.82 to $74.26 \%$, HDEA from 18.95 to $89.82 \%$. HDBU from 2.78 to $40.22 \%$. HDET from 0.00 to $22.22 \%$, and HDAQ from 6.30 to $5.16 \%$. The EC50 values were calculated from the linear portions of the doseresponse curves of scavenging activity as shown in Figure 5A. The EC50 values of HDEA and HDHE fraction were 535 and $1,081 \mu \mathrm{g} / \mathrm{mL}$, respectively. On the other hand, the EC50 value of HDET, HDBU and HDAQ fractions was more than 3,000 $\mu \mathrm{g} / \mathrm{mL}$. Thus, HDEA and HDHE showed high scavenging activity of DPPH radicals, while HDET, HDBU and HDAQ showed low and very low scavenging activity. By contrast, the EC50 values of vitamin $\mathrm{C}$ and quercetin, used as positive controls, were 6.66 and $2.37 \mu \mathrm{g} / \mathrm{mL}$, respectively, which were $200-450$ folds higher than HDEA and HDHE fractions since they are pure compounds. The ABTS $\bullet+$-scavenging ability reflecting the anti-oxidation capacities of HDHE ranged from 31.28 to $86.18 \%$, HDEA from 41.28 to $93.27 \%$, HDBU from 18.61 to $48.22 \%$, HDET from 0.00 to $25.90 \%$, and HDAQ, from 15.24 to $20.98 \%$. The EC50 values were calculated from the linear portions of the dose-response curves as shown in Figure 5B. The EC50 values of HDEA and HDHE were 669 and 1,639 $\mu \mathrm{g} / \mathrm{mL}$, respectively. On the other hand, the EC50 value of HDET, HDBU and HDAQ fractions was more than $3,000 \mu \mathrm{g} / \mathrm{mL}$. Thus, HDHE, HDEA had relatively high while HDET, HDBU and HDAQ fractions showed very low anti-oxidation activity. In comparison EC50 values of vitamin $\mathrm{C}$ and quercetin, used as positive controls, were $4.82,8.43 \mu \mathrm{g} / \mathrm{mL}$, which indicated that HDEA and HDHE fractions have much lower antioxidation activity when compared to these pure compounds. EC50 values of DPPH and ABTS assay were shown in Table 5.

It can be concluded from DPPH and ABTS assays that the highest to lowest antioxidant effect was detected in the HDEA, HDHE, HDET, while HDAQ showed very low antioxidant activity. The high antioxidants were expected to be present in the non-polar extract which might contain non-polar phytochemicals. Antioxidant activity of HDEA being the highest might be because it contained various phytochemicals such as alkaloids, flavonoids, terpenoids, steroids, glycoside, and saponins. The second highest antioxidation activity was observed in HDHE fraction. This fraction also contained phytochemicals that include alkaloids, flavonoids, terpenoids, steroids, glycosides, saponins, and carotenoids with lower concentrations. The third highest antioxidant activity was observed in HDET fraction, which also contained alkaloids, flavonoids, terpenoids, steroids, glycoside, and saponins in lowest concentrations. In a preliminary investigation, we found that HDET, HDHE and HDEA fractions have similar phytochemicals including alkaloids, flavonoids, terpenoids, steroids, glycosides, and saponin but they might be at lowest concentrations in HDET. Thus, HDET has lower antioxidant activity than HDEA and HDHE. Lastly, HDAQ contained low concentrations of flavonoids and glycosides and may be also sulfated polysaccharides, a group of highly polar molecules, which explained its lowest antioxidant capacity.

Table 5 EC50 values of DPPH and ABTS assay.

\begin{tabular}{ccc}
\hline & \multicolumn{2}{c}{$\mathbf{E C 5 0}(\boldsymbol{\mu g} / \mathbf{m L})$} \\
\cline { 2 - 3 } Fractions & DPPH assay & ABTS assay \\
\hline Vitamin C & 6.66 & 2.37 \\
Quercetin & 4.82 & 8.43 \\
HD-ET & $>3,000.00$ & $>3,000.00$ \\
HD-HE & $1,081.00$ & $1,639.00$ \\
HD-EA & 535.00 & 669.00 \\
HD-BU & $>3,000.00$ & $>3,000.00$ \\
HD-AQ & $>3,000.00$ & $>3,000.00$
\end{tabular}


(A)

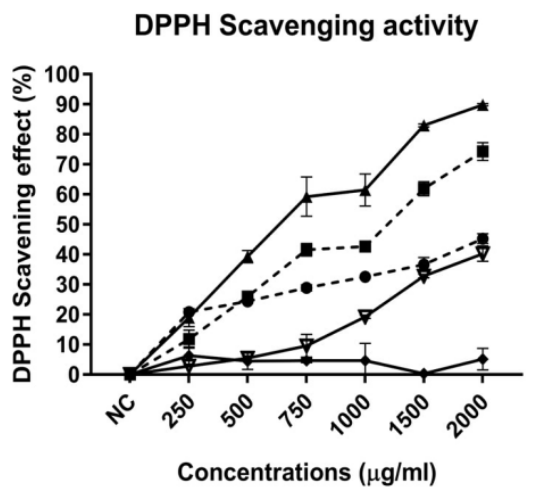

(B)

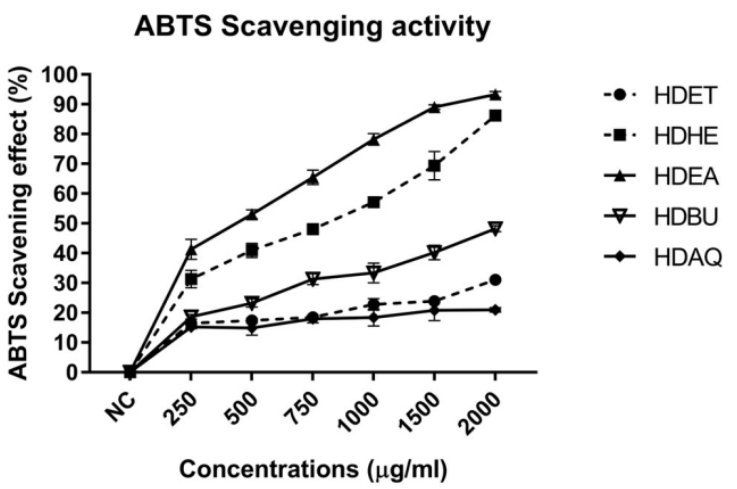

Figure 5 DPPH and ABTS scavenging activity of 5 fractions from $H$. durvillei extracts. Each value is presented as mean \pm standard error $(n=3)$. The results were used to generate trendlines and calculate EC50 values.

\section{Conclusions}

In summary, we have investigated cytotoxic, genotoxic, and antioxidant effects of ethanol, hexane, ethyl acetate, butanol and aqueous extract fractions from $H$. durvillei in the in vitro models, using different cell types including hepatocyte, fibroblast, macrophage and keratinocyte in order to assess the nontoxic concentrations of the extracts from this sea weed that could be safely utilized in the food, cosmetic and drug developments, and we found that HDET and HDAQ practically had no toxicity and HDHE, HDEA, and HDBU could be safely consumed at doses lower than $100 \mu \mathrm{g} / \mathrm{mL}$. However, it is crucial to verify whether the effects observed in these in vitro assays concur with in vivo assays which need to be investigated further.

\section{Acknowledgements}

This research was supported by the grants from the Thailand Research Fund (TRF)- Research and Researcher for Industry (RRi; MSD61I0035) and the Agricultural Research Development Agency (Public Organization).

\section{References}

[1] J Fleurence. Seaweed proteins: Biochemical, nutritional aspects and potential uses. Trends Food Sci. Tech. 1999; 10, 25-8.

[2] ML Wells, P Potin, JS Craigie, JA Raven, SS Merchant, KE Helliwell, AG Smith, ME Camire and $\mathrm{SH}$ Brawley. Algae as nutritional and functional food sources: Revisiting our understanding. $J$. Appl. Phycol. 2017; 29, 949-82.

[3] WB John, RC Brent, HGM Murray, TN Peter and RP Michèle. Marine natural products. Nat. Prod. Rep. 2005; 22, 15-61.

[4] A Jiménez-Escrig, E Gómez-Ordóñez and P Rupérez. Brown and red seaweeds as potential sources of antioxidant nutraceuticals. J. Appl. Phycol. 2012; 24, 1123-32.

[5] TA Fenoradosoa, C Delattre, C Laroche, A Wadouachi, V Dulong, L Picton, P Andriamadio and P Michaud. Highly sulphated galactan from Halymenia durvillei (Halymeniales, Rhodophyta), a red seaweed of Madagascar marine coasts. Int. J. Biol. Macromol. 2009; 45, 140-5.

[6] S Meesala, P Gurung, K Karmodiya, P Subrayan and MG Watve. Isolation and structure elucidation of halymeniaol, a new antimalarial sterol derivative from the red alga Halymenia floresii. J. Asian Nat. Prod. Res. 2018; 20, 391-8.

[7] M Vinosha, S Palanisamy, R Anjali, C Li, K Yelithao, T Marudhupandi, M Tabarsa, SG You and NM Prabhu. Sulfated galactan from Halymenia dilatata enhance the antioxidant properties and prevents Aeromonas hydrophila infection in tilapia fish: In vitro and in vivo study. Int. J. Biol. Macromol. 2020; 158, 569-79.

[8] P Manohong, N Sornkaew, K Meemon, K Chumphoochai, P Sobhon, M Tamtin, J Sichaem, W Mingvanish, C Srisuwannaket, W Mingvanish and N Niamnont. Isolation of 3-(Hydroxyacetyl) 
indole and Indole-3-carboxylic acid from Red Alga Halymenia durvillei: Their anti-lung cancer cell and in vivo anti-aging activity. Asian J. Chem. 2021; 33, 775-80.

[9] B Halliwell. Antioxidants in human health and disease. Ann. Rev. Nutr. 1996; 16, 33-50.

[10] B Halliwell, JMC Gutteridge and CE Cross. Free radicals, antioxidants and human disease: Where are we now? J. Lab. Clin. Med. 1992; 119, 598-620.

[11] OI Aruoma. Nutrition and health aspects of free radicals and antioxidants. Food Chem. Toxicol. 1994; 32, 671-83.

[12] S Srivastava, S Mishra, J Dewangan, A Divakar, PK Pandey and SK Rath. Principles for in vitro toxicology. In: A Dhawan and S Kwon (Eds.). In vitro toxicology. Academic Press, Massachusetts, 2018, p. 21-43.

[13] AK Jain, D Singh, K Dubey, R Maurya, S Mittal and AK Pandey. Models and methods for in vitro toxicity. In vitro toxicology. Academic Press, Massachusetts, 2018, p. 45-65.

[14] SC Nicklisch and JH Waite. Optimized DPPH assay in a detergent-based buffer system for measuring antioxidant activity of proteins. MethodsX 2014; 1, 233-8.

[15] Z Mellouk, I Benammar, D Krouf, M Goudjil, M Okbi and W Malaisse. Antioxidant properties of the red alga Asparagopsis taxiformis collected on the North West Algerian coast. Exp. Ther. Med. 2017; 13, 32812-90.

[16] A Floegel, DO Kim, SJ Chung, SI Koo and OK Chun. Comparison of ABTS/DPPH assays to measure antioxidant capacity in popular antioxidant-rich US foods. J. Food Compos. Anal. 2011; 24, 1043-8.

[17] V Zacchino, G Centoducati, M Narracci, M Selvaggi and MP Santacroce. Effects of benzo [a] pyrene on gilthead sea bream (Sparus aurata L.) hepatocytes exposed in vitro to short and long term trials. Ital. J. Anim. Sci. 2013; 12, e17.

[18] J Bouayed, L Hoffmann and T Bohn. Total phenolics, flavonoids, anthocyanins and antioxidant activity following simulated gastro-intestinal digestion and dialysis of apple varieties: Bioaccessibility and potential uptake. Food Chem. 2011; 128, 14-21.

[19] LMT Kashani, M Majdzadeh, M Khanavi, M Taghizadeh, N Sadati, N Kahkeshani, M Vatankhah and SN Ostad. Cytotoxic activity of selected Iranian traditional medicinal plants on colon, colorectal and breast cancer cell lines. Arch. Breast. Canc. 2014; 1, 95-8.

[20] K Abe and K Yanagisawa. A new class of rapidly developing mutants in Dictyostelium discoideum: implications for cyclic AMP metabolism and cell differentiation. Dev. Biol. 1983; 95, 200-10.

[21] MF Melzig, G Bader and R Loose. Investigations of the mechanism of membrane activity of selected triterpenoid saponins. Planta Med. 2001; 67, 43-8.

[22] C Gauthier, J Legault, M Piochon-Gauthier and A Pichette. Advances in the synthesis and pharmacological activity of lupane-type triterpenoid saponins. Phytochem. Rev. 2011; 10, 521-44.

[23] A Galanty, M Michalik, Ł Sędek and I Podolak. The influence of LTS-4, a saponoside from Lysimachia thyrsiflora L., on human skin fibroblasts and human melanoma cells. Cell. Mol. Biol. Lett. 2008; 13, 585-98.

[24] P Cmoch, Z Pakulski, J Swaczynová and M Strnad. Synthesis of lupane-type saponins bearing mannosyl and 3, 6-branched trimannosyl residues and their evaluation as anticancer agents. Carbohydr. Res. 2008; 343, 995-1003.

[25] R Tundis, M Bonesi, B Deguin, MR Loizzo, F Menichini, F Conforti, F Tillequin and F Menichini. Cytotoxic activity and inhibitory effect on nitric oxide production of triterpene saponins from the roots of Physospermum verticillatum (Waldst \& Kit) (Apiaceae). Bioorg. Med. Chem. 2009; 17, 4542-7.

[26] X Ma, L Xie, L Liu, Q Tang, Z Wan and Y Li. Simultaneous quantification of seven main triterpenoid saponins in Radix et Rhizoma Clematidis by LC-ELSD. Chromatographia 2009; 69, 437-43.

[27] L Mskhiladze, J Legault, S Lavoie, V Mshvildadze, J Kuchukhidze, R Elias and A Pichette. Cytotoxic steroidal saponins from the flowers of Allium leucanthum. Molecules 2008; 13, 2925-34.

[28] A Sánchez-Medina, PC Stevenson, S Habtemariam, LM Peña-Rodríguez, O Corcoran, AI Mallet and NC Veitch. Triterpenoid saponins from a cytotoxic root extract of Sideroxylon foetidissimum subsp. Gaumeri. Phytochemistry 2009; 70, 765-72.

[29] AI Hamed, S Piacente, G Autore, S Marzocco, C Pizza and W Oleszek. Antiproliferative hopane and oleanane glycosides from the roots of Glinus lotoides. Planta Med. 2005; 71, 554-60.

[30] AA Magid, L Voutquenne-Nazabadioko, I Renimel, D Harakat, C Moretti and C Lavaud. Triterpenoid saponins from the stem bark of Caryocar villosum. Phytochemistry 2006; 67, 2096102. 
[31] P Fowler, R Smith, K Smith, J Young, L Jeffrey, P Carmichael, D Kirkland and S Pfuhler. Reduction of misleading ("false") positive results in mammalian cell genotoxicity assays. III: Sensitivity of human cell types to known genotoxic agents. Mutat. Res. 2014; 767, 28-36.

[32] FM Tonelli, VA Goulart, KN Gomes, MS Ladeira, AK Santos, E Lorençon, LO Ladeira and RR Resende. Graphene-based nanomaterials: Biological and medical applications and toxicity. Nanomedicine 2015; 10, 1-28.

[33] G Gajski, V Garaj-Vrhovac and V Oreščanin. Cytogenetic status and oxidative DNA-damage induced by atorvastatin in human peripheral blood lymphocytes: Standard and Fpg-modified comet assay, Toxicol. Appl. Pharm. 2008; 231, 85-93.

[34] FV Goethem, D Lison and M Kirsch-Volders. Comparative evaluation of the in vitro micronucleus test and the alkaline single cell gel electrophoresis assay for the detection of DNA damaging agents: genotoxic effects of cobalt powder, tungsten carbide and cobalt-tungsten carbide. Mutat. Res. 1997; 392, 31-43.

[35] RF Lee and S Steinert. Use of the single cell gel electrophoresis/comet assay for detecting DNA damage in aquatic (marine and freshwater) animals. Mutat. Res. 2003; 544, 43-64.

[36] M Fenech, M Kirsch-Volders, AT Natarajan, J Surralles, JW Crott, J Parry, H Norppa, DA Eastmond and $\mathrm{P}$ Thomas. Molecular mechanisms of micronucleus, nucleoplasmic bridge and nuclear bud formation in mammalian and human cells. Mutagenesis 2011; 26, 125-32. 